\title{
DRYING BEHAVIOUR OF SECOND-GROWTH NOTHOFAGUS ALPINA
}

\author{
Rubén A. Ananias ${ }^{1}$, Gonzalo Hernandez ${ }^{2}$, Emilio Vergara ${ }^{1}$
}

\begin{abstract}
Wood drying quality and transversal permeability of Chilean second-growth Nothofagus alpina (raulí) were evaluated. Two charges of raulí sawnwood were dried in a experimental kiln. One of the charges was prepared with sawnwood from Pinto the second one was prepared with sawnwood from Collipulli. The transverse permeability to air of the material after drying was determined. The results showed that the drying rate was $25 \%$ higher and drying time was about $18 \%$ shorter for Collipulli sawnwood (from green to 12\%) due to the extent of heartwood. The shrinkage, collapse and drying stress were less in the wood dried from Collipulli, while the transverse permeability was lower in the samples from Pinto.
\end{abstract}

Keywords: Drying quality, permeability, raulí, collapse.

\section{INTRODUCTION}

Nothofagus alpina (raulí) is a very important Chilean native species with nice, even-textured grain, somewhat similar to the New Zealand silver beech (Nothofagus menziesii) but with a more pronounced reddish-brown hue (Olson 2003). Because of its high value, raulí was excessively exploited in the past and now accounts for only some $10 \%$ of the total cut of Chilean hardwoods. However, there are now about 1.2 Mha of productive regrowth of Nothofagus spp., much of it raulí $\left(\right.$ CONAF 1999, Gezan ${ }^{3}$ ). This resource is now being studied to evaluate the potential of the secondgrowth wood as raw material for furniture and other high-value end use. An important aspect of these studies concerns the determination of drying schedules and the drying behaviour.

INFOR (1990) explored possibilities of potential uses of second-growth raulí on the basis of the physical and mechanical properties. INFOR (1994) showed that second-growth raulí is relatively easy to dry with about to $6 \%$ of total volumetric shrinkage and air pre-drying times from 90 to 150 days. The drying time ranged from 8 to 37 days for 25 and $50 \mathrm{~mm}$ thick respectively (INFOR 1994, 1997). Ananías et al. (1994) showed that freshly-cut wood had a superior permeability and a somewhat larger drying rate than stored wood, but its total drying time was longer due to the higher initial moisture content. They also determined that wood quality after drying was generally better in fresh second-growth raulí. In addition, they found more permeability in fresh samples and also they noted that permeability to air and water are of the same order as predicted by theory (Siau 1995). When the dry wood was checked for quality, the fresh wood had less cup and and crook but more twist and checks (Ananías et al. 1994).

The present study was undertaken to investigate the drying behaviour of $50 \mathrm{~mm}$ boards of second-growth Nothofagus alpina and examine possibilities of improving the quality of drying.

\footnotetext{
${ }^{1}$ Departamento de Ingeniería en Maderas, Facultad de Ingeniería, Universidad del Bío-Bío, Concepción, CHILE ${ }^{2}$ Departamento Industrias, INFOR, Concepción, CHILE. ghernand@infor.cl

Corresponding autor: ananias@ubiobio.cl

Received: 13.06.2009 Accepted: 21.01.2010 


\section{MATERIALS AND METHODS}

Sixty experimental trees were harvested in a regrowth forest of Nothofagus alpina (Poepp et. Endl.) taken from near Collipulli (IX Region of Chile) and near Pinto (VIII Region of Chile). Sampling of the trees was undertaken according to Chilean Standard NCH 968 (INN 1986).The characteristics of the logs are showed in Table 1.

Table 1: Logs characteristics of second-growth raulí (Nothofagus alpina)

\begin{tabular}{|c|c|c|c|}
\hline Trees & $\begin{array}{c}\text { Diameter } \\
(\mathrm{cm})\end{array}$ & $\mathbf{N}^{\mathbf{0}}$ growth annual rings & $\begin{array}{c}\text { Basic density } \\
\left(\mathrm{kg} / \mathrm{m}^{3}\right)\end{array}$ \\
\hline Collipulli & $23(8)$ & $48(6)$ & $500(40)$ \\
\hline Pinto & $34(4)$ & $75(6)$ & $500(40)$ \\
\hline
\end{tabular}

$\mathrm{n}=30$, (standard deviation)

180 boards of nominal dimensions 50x $125 \times 1800 \mathrm{~mm}$ were prepared, three per tree, and distributed at random into two lots for drying and permeability tests. For drying, the first lot was prepared from Collipulli trees whereas the second lot was prepared from Pinto trees. The sawnwood was dried in a vapor-heated experimental kiln of $0.25 \mathrm{~m}^{3}$ capacity with an air-circulation velocity of $2.5 \mathrm{~m} / \mathrm{s}$. The drying schedule was adopted from INFOR (1994). The dry-bulb temperature rose from 48 to $80{ }^{\circ} \mathrm{C}$ and the wet-bulb temperature varied from $46{ }^{\circ} \mathrm{C}$ to $58{ }^{\circ} \mathrm{C}$ at the end. At the beginning, a pretreatment at $80{ }^{\circ} \mathrm{C}$ in a saturated atmosphere was given for eight hours. At $18 \%$ moisture content, the charges were reconditioned for six hours under the same conditions. At the end the dried wood was conditioned at $80{ }^{\circ} \mathrm{C}$ for eight hours in a saturated atmosphere. The moisture content of each charge was determined at appropriate times by weighing three sample boards of $0.5 \mathrm{~m}$ length and confirmed by oven-drying small sections. The shrinkage and collapse were evaluated according to Chilean Standard NCH 176/3 (INN 1984) and the moisture gradient and drying stresses calculated as shown by Welling (1994).

Air-permeability measurements were made on specimens prepared after conditioning to $12 \%$ moisture content. Sampling and conditioning was carried out in accordance with the Chilean Standard (INN 1986). The permeability of the material was measured on cylindrical specimens of 76 $\mathrm{mm}$ diameter and $6 \mathrm{~mm}$ length in the radial and tangential direction, respectively, using an apparatus described by Kauman et al. (1994). The specimens were held against a seat in the permeability cell by a strong spring and a secure seal was achieved by an O-ring. Specific permeability was calculated by means of Equation 1 (Siau 1995).

$$
K_{G}=\frac{Q_{G} \cdot L \cdot P}{A \cdot \Delta P \cdot P^{\prime}} \cdot \eta
$$

where $\mathrm{K}_{\mathrm{G}}$ is the specific permeability of air in $\mathrm{m}^{2}, \mathrm{Q}_{\mathrm{G}}$ the flow rate in $\mathrm{m}^{3} / \mathrm{s}$, $\mathrm{L}$ the flow length in $\mathrm{m}, \mathrm{P}$ is the pressure in $\mathrm{Pa}$ at which the flow $\mathrm{Q}$ is measured, $\mathrm{A}$ the flow area in $\mathrm{m}^{2}, \Delta \mathrm{P}$ the pressure drop in $\mathrm{Pa}, \mathrm{P}^{\prime}$ the mean absolute pressure within the specimen in $\mathrm{Pa}$, and $n$ the viscosity in $\mathrm{Pa}$.s. 


\section{RESULTS AND DISCUSSION}

Figure 1 shows the drying curves for the two drying runs. The drying rates were approximately $25 \%$ faster in sawnwood from Collipulli, as the run from Pinto took about $18 \%$ longer to dry. This difference is due to the effects of the characteristics of the trees (Table 1), there being a larger diameter and more annual growth rings with the trees from Pinto. This may suggest more extensive heartwood in this material, as observed before (INFOR 1994).

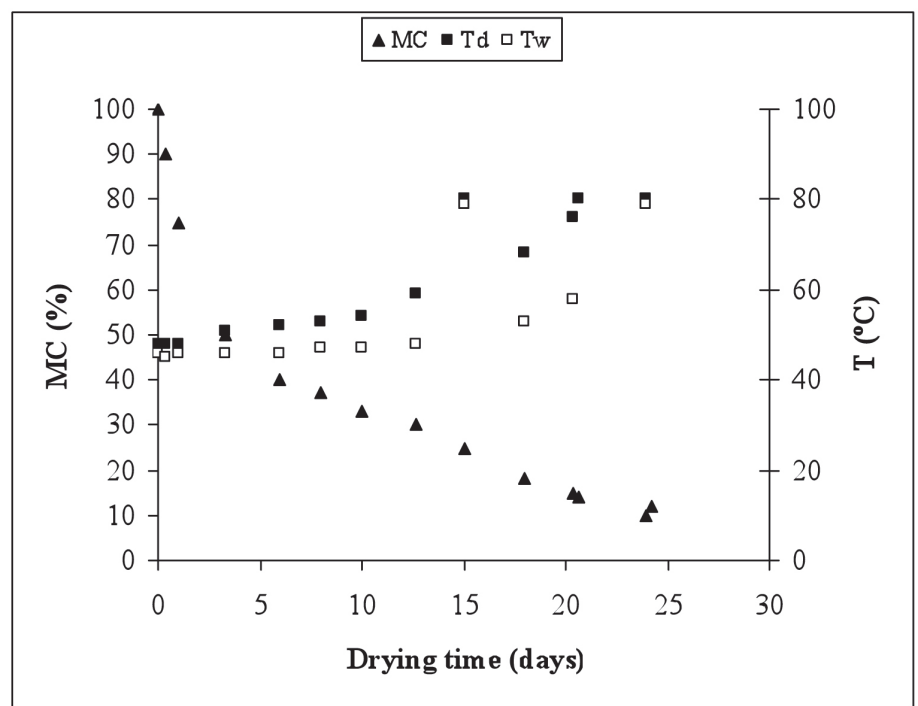

a) Raulí from Collipulli

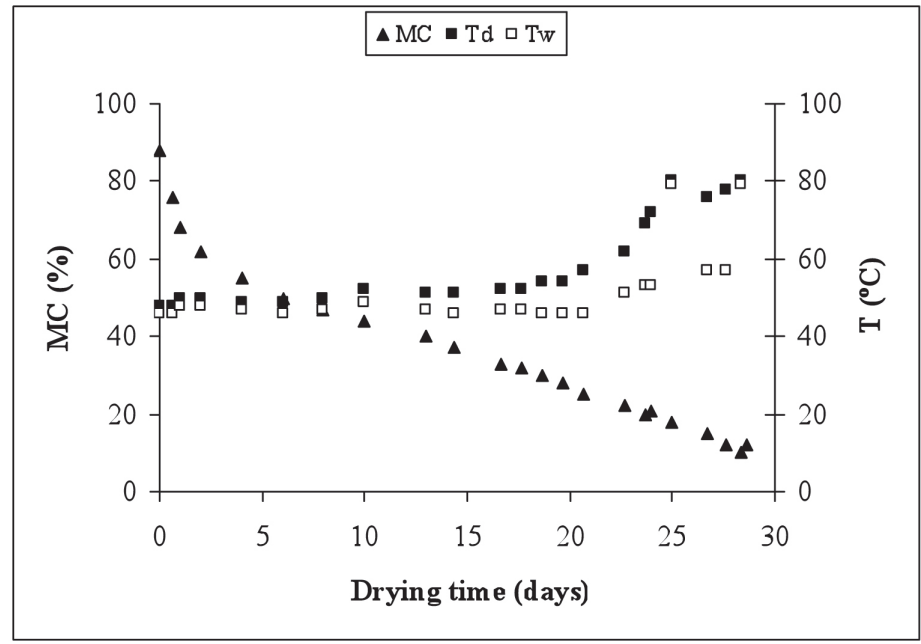

b) Raulí from Pinto

Figure 1: Drying curves of second-growth raulí (Nothofagus alpina)

Table 2 gives the shrinkage and collapse estimated as proposed by INN (1984). The overall shrinkage and collapse were lower for material dried from Collipulli. This may be due to greater drying stresses in material dried from Pinto (Table 3). 
Table 2: Wood drying shrinkage and collapse of second-growth raulí (Nothofagus alpina)

\begin{tabular}{|c|c|c|c|c|c|c|}
\hline \multirow{2}{*}{ Wood samples } & \multicolumn{6}{|c|}{ Transversal shrinkage (\%) } \\
\cline { 2 - 7 } & \multicolumn{2}{|c|}{ B.R. at 18 \% MC } & \multicolumn{2}{|c|}{ A.R. at 18\% MC } & \multicolumn{2}{|c|}{ A.R. at 12\% MC } \\
\cline { 2 - 7 } & Radial & Tangential & Radial & Tangential & Radial & Tangential \\
\hline Collipulli & $2.0(0.3)$ & $3.6(0.4)$ & $1.8(0.2)$ & $3.1(0.4)$ & $2.7(0.4)$ & $4.6(0.6)$ \\
\hline Pinto & $3.0(1.0)$ & $4.2(1.3)$ & $2.5(1.0)$ & $3.9(1.3)$ & $3.9(1.1)$ & $5.9(1.2)$ \\
\hline
\end{tabular}

$\mathrm{n}=15$, (standard deviation), B.R.: before reconditioning, A.R.: after reconditioning

Table 3: Moisture content, moisture gradient and drying stresses of second-growth raulí (Nothofagus alpina)

\begin{tabular}{|c|c|l|c|c|}
\hline \multirow{2}{*}{ Wood samples } & \multicolumn{3}{|c|}{ Moisture content (\%) } & $\begin{array}{c}\text { Drying stresses } \\
(\mathrm{mm})\end{array}$ \\
\cline { 2 - 5 } & Initial & Final & Final gradient & \\
\hline Collipulli & $100(14)$ & $12(2)$ & $2(3)$ & $1(2)$ \\
\hline Pinto & $89(7)$ & $12(2)$ & $2(4)$ & $2(3)$ \\
\hline
\end{tabular}

$\mathrm{n}=12$, (standard deviation)

However, these second-growth raulí are faster to dry and have less shrinkage and collapse than when virgin Chilean coigüe is dried (Kauman and Mittak 1964).

Table 4 shows the results for flow rate and air permeability. The flow rate and permeability to air were higher in wood from Collipulli. This may be related to the less extensive heartwood with smaller-diameter trees and narrower annual growth rings (Table 1). The air permeability in these experiments was of the same order that the water permeability of second-growth rauli (Ananias et al. 1994). It is 100 times lower than observations on tepa Laurelia philippiana (Kauman et al. 1994). This difference may be a reflection of the very fine structure of raulí. The air permeability of secondgrowth Nothofagus alpina was also lower by a factor of 10 than observations on sapwood of New Zealand red beech Nothofagus fusca (Kinninmonth 1971).

Table 4: Transversal flow rate and air permeability of second-growth raulí (Nothofagus alpina)

\begin{tabular}{|c|c|c|c|c|}
\hline \multirow{2}{*}{ Wood samples } & \multicolumn{2}{|c|}{$\mathbf{Q}_{\mathrm{G}} \mathbf{x} 10^{\mathbf{8}}\left(\mathbf{m}^{3} / \mathbf{s}\right)$} & \multicolumn{2}{|c|}{$\mathbf{K}_{\mathrm{G}} \mathbf{x 1 0} \mathbf{1 0}^{18}\left(\mathbf{m}^{2}\right)$} \\
\cline { 2 - 5 } & Radial & Tangential & Radial & Tangential \\
\hline Collipulli & $29.2(12.1)$ & $27.6(15.9)$ & $7.5(1.0)$ & $3.8(0.3)$ \\
\hline Pinto & $9.8(6.8)$ & $4.7(5.2)$ & $3.1(0.4)$ & $1.7(0.7)$ \\
\hline
\end{tabular}

$\mathrm{n}=16,($ standard deviation) 
The flow rate and permeability were smaller in the Pinto specimens, due to the more extensive heartwood in this material. As the drying rates were also lower in these specimens (Figure $1 \mathrm{a} \mathrm{y} \mathrm{b}$ ), it may be surmised that the rate-controlling mechanism was diffusion and not permeability. This hypothesis would, however, need to be confirmed by independent measurements.

\section{CONCLUSIONS}

Kiln drying of $50 \mathrm{~mm}$ second-growth raulí with a schedule starting at $48{ }^{\circ} \mathrm{C}$ dry bulb temperature and rising to $76^{\circ} \mathrm{C}$ at the end of drying took 25 days from green $(100 \%)$ to $12 \%$ moisture content. The quality of drying was satisfactory when the boards were from sourced from Collipulli but not quite as good when they were from Pinto. In addition, there was some collapse in the Pinto material, while the drying time was $18 \%$ longer due to the more extensive heartwood. The small permeability of the raulí specimens suggests that diffusion is the controlling mechanism.

\section{REFERENCES}

Ananías, R.A.; Steinhagen, H.P.; Vergara, E.; Hernández, G. 1994. Drying of second growth Nothofagus alpina sawnwood. Preliminary results. Proceeding $4^{\text {th }}$ IWDC. Rotorua, New Zealand. Poster 6pp.

CONAF. 1999. Catastro y evaluación de recursos vegetacionales nativos de Chile. Informe nacional con variables ambientales. Proyecto Conaf-Conama-Birf. 89p.

INFOR. 1997. Monografía de raulí Nothofagus alpina. Instituto Forestal, Santiago, Chile.

INFOR. 1994. Secado de madera de renovales de roble y raulí. Informe Técnico $N^{\circ} 134$, Instituto Forestal, Santiago-Chile.

INFOR. 1990. Propiedades mecánicas de especies madereras de corta rotación. Informe Técnico $\mathrm{N}^{\circ}$ 121, Instituto Forestal, Santiago-Chile.

INN. 1986. Madera. Selección, obtención y acondicionamiento de muestras y probetas para la determinación de propiedades físicas y mecánicas. Norma chilena oficial NCh 968. Of86. Instituto Nacional de Normalización, Santiago-Chile.

INN. 1984. Madera. Parte 3: Determinación de la contracción radial y tangencial Norma chilena oficial NCh 176/3. Of84. Instituto Nacional de Normalización, Santiago-Chile.

Kauman, W.G.; Ananías, R.A.; Gutiérrez, M.; Valenzuela, H. 1994. Non-Darcian permeability in Chilean tepa (Laurelia philippiana). Holzforschung 48(Suppl.):77-81.

Kauman, W.G.; Mittak, G. 1964. Problems in drying Chilean coigüe. Forest Products Journal 14(8):359-360.

Kinninmonth, J.A. 1971. Permeability and fine structure of certain hardwoods and effects on drying I. Transverse permeability of wood to micro-filtered water. Holzforschung 25(4): 127-133. 
Olson, S.M. 2003. The wood properties of New Zealand silver beech (Nothofagus menziesii), a lesserknown hardwood species. Forest Products Journal 53(5):80-86.

Siau, J. F. 1995. Wood: Influence of moisture on physical properties. Department of Wood Science and Forest Products, Virginia Polytechnic Institute and State University. USA.

Welling, J. 1994. Drying quality assessment and specification - a challenge for the future. Proceeding $4^{\text {th }}$ IWDC, 297-304. Rotorua, New Zealand. 